\title{
Interhemispheric epidermoid cyst
}

\author{
Mark Schembri, ${ }^{1}$ Reuben Grech ${ }^{2}$
}

${ }^{1}$ Mater Dei Hospital, Msida, Malta

${ }^{2}$ Department of

Neuroradiology, Beaumont

Hospital, Dublin, Ireland

\section{Correspondence to}

Dr Mark Schembri,

schem097@gmail.com

Accepted 9 November 2015

\section{DESCRIPTION}

A 44-year-old man presented following a tonicclonic seizure. Intracranial epidermoid cysts account for approximately $1 \%$ of primary intracranial tumours. They are benign slow growing tumours derived from ectodermal inclusions during neural tube closure. Typical presentation is between the ages of 20 and 40 years.

Epidermoid cysts are frequently found in the cerebellopontine angle, being the third commonest lesion at this site, following vestibular schwannomas and meningiomas. Lesions arising in the interhemispheric fissure are rare, accounting for approximately $4 \%$ of all intracranial locations. ${ }^{1}$

Clinical presentation is related to gradual mass effect and depends largely on the location of the tumour, the commonest symptoms being hearing loss, trigeminal neuralgia and headaches. Incidence of seizures is higher in patients with supratentorial lesions. $^{2}$

On CT, epidermoids appear as lobulated hypoattenuating lesions that exert gradual mass effect (figure 1). MRI is the imaging modality of choice with the lesion often indistinguishable from arachnoid cysts on many sequences (figure 1). The characteristic heterogeneous/dirty signal on fluidattenuated inversion recovery and restricted diffusion, owing to a combination of true restricted diffusion and T2 shine-through, aid in differentiating epidermoid cysts from arachnoid cysts (figure 2). Most epidermoid cysts do not enhance, although minimal rim enhancement occurs in approximately $25 \%$ of cases. ${ }^{3}$

Surgical excision remains the mainstay of treatment, often with incomplete resection due to adherence of the capsule to important neurovascular structures. At surgery, the tumour has an

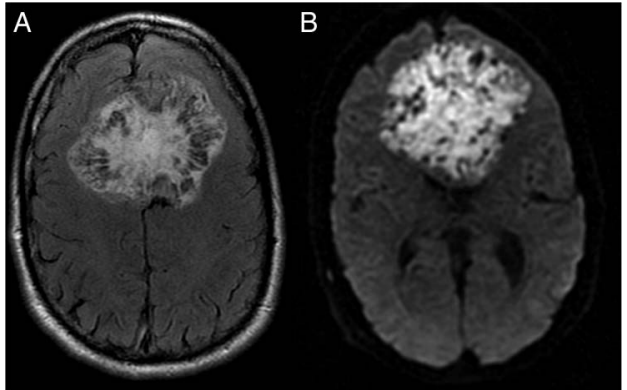

Figure 2 Axial fluid-attenuated inversion recovery image (A) demonstrating a characteristic heterogeneous/ dirty signal and diffusion-weighted image (B) showing restricted diffusion.

irregular cauliflower outer surface and is composed of a pearly material lending the name 'beautiful tumour'.

\section{Learning points}

- The interhemispheric fissure is a rare but recognised site of intracranial epidermoid cysts.

- Intracranial epidermoid cysts demonstrate characteristic MR findings on diffusion-weighted imaging and fluid-attenuated inversion recovery sequences, allowing for accurate diagnosis in an atypical location.

Contributors MS performed the literature review and drafted the write up. RG was responsible for the images provided, review and final approval of the submitted article.
CrossMark

To cite: Schembri M, Grech R. BMJ Case Rep Published online: [please include Day Month Year] doi:10.1136/bcr-2015213393

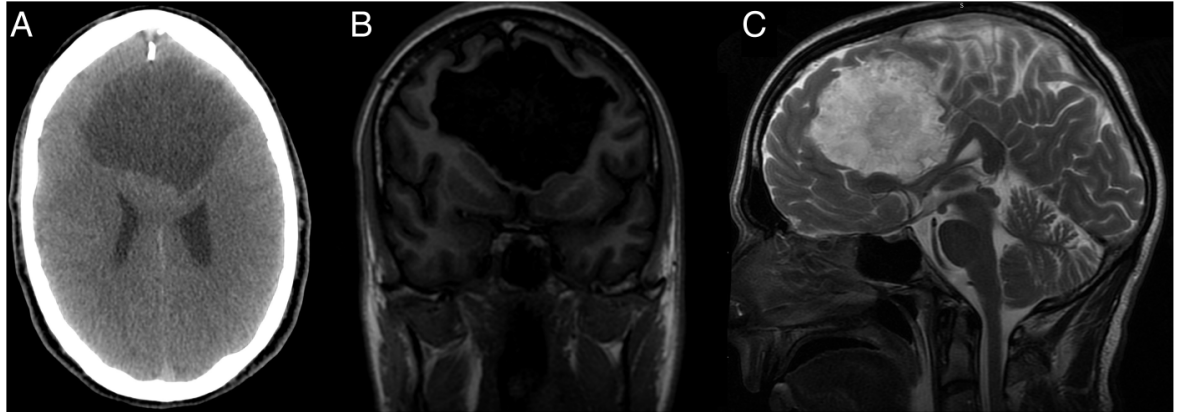

Figure 1 Axial unenhanced $\mathrm{CT}$ image $(\mathrm{A})$ showing a lobulated hypoattenuating lesion in the interhemispheric region. Coronal T1-weighted image (T1WI) postcontrast (B) showing a non-enhancing hypointense lesion in the interhemispheric fissure and sagittal T2WI (C) showing a hyperintense signal within the lesion. 
Competing interests None declared.

\section{Patient consent Obtained.}

Provenance and peer review Not commissioned; externally peer reviewed.

\section{REFERENCES}

1 Agarwal V, Vijayan A, Velho V, et al. Pearl in interhemispheric fissure: a rare phenomenon. Asian J Neurosurg 2012;7:229.
2 Chowdhury FH, Haque MR, Sarker MH. Intracranial epidermoid tumor; microneurosurgical management: an experience of 23 cases. Asian J Neurosurg 2013;8:21-8.

3 Osborn AG, Preece MT. Intracranial cysts: radiologic-pathologic correlation and imaging approach. Radiology 2006;239:650-64.

Copyright 2015 BMJ Publishing Group. All rights reserved. For permission to reuse any of this content visit http://group.bmj.com/group/rights-licensing/permissions.

BMJ Case Report Fellows may re-use this article for personal use and teaching without any further permission.

Become a Fellow of BMJ Case Reports today and you can:

- Submit as many cases as you like

- Enjoy fast sympathetic peer review and rapid publication of accepted articles

- Access all the published articles

- Re-use any of the published material for personal use and teaching without further permission

For information on Institutional Fellowships contact consortiasales@bmjgroup.com

Visit casereports.bmj.com for more articles like this and to become a Fellow 